\title{
Notes on the axial skeleton of the titanosaur Bonitasaura salgadoi (Dinosauria-Sauropoda)
}

\author{
PABLO A. GALLINA \\ CONICET, Área de Paleontología, Fundación de Historia Natural "Félix de Azara" \\ CEBBAD - Universidad Maimónides, Hidalgo 775, $7^{\circ}$ piso, (1405) Ciudad Autónoma de Buenos Aires, Argentina \\ Manuscript received on October 8, 2009; accepted for publication on September 14, 2010
}

\begin{abstract}
Sauropod axial anatomy is particularly important in understanding morphological features and phylogenetic analyses. Spatial arrangement of zygapophyses and rib articulations, as well as their complex laminar development, help to recognize the relative position of isolated vertebral elements. The presence of anterior, mid and posterior elements along the cervical, dorsal and caudal series in Bonitasaura salgadoi allows the analysis of several anatomical characteristics. These include the pattern of neurocentral closure with unfused, partially fused and completely fused elements in a peculiar temporal sequence, as well as several neural spine modifications and the laminar arrangement. The variations in neural spine morphology include a lateral expansion of the distal tip in cervico-dorsal region, different lateral constituents of these lateral expansions, and a marked deviation in spine angulation. The spinal inclination allows the division into three easily recognizable vertebral regions separated by two landmarks, which adds support in the determination of an accurate vertebral position for isolated elements. Finally, an analysis of the vertebral laminae reveals the importance of examining vertebral series in order to recognize laminar homologies and developmental series. Two vertebral laminae are analyzed here.
\end{abstract}

Key words: Dinosauria, neural spine, neurocentral closure, Sauropoda, Titanosauria, vertebral laminae.

\section{INTRODUCTION}

Titanosaurs were the last surviving group of sauropod dinosaurs. Although their global distribution has been recorded over Late Jurassic to Early Cretaceous times, their diversity (with a large variety of forms) has showed a noticeable pinnacle in the Late Cretaceous of the already isolated continent of South America (Powell 2003). After a long coexistence of diplodocoids and basal titanosaurs during the Early Cretaceous and the beginnings of the Late Cretaceous, derived titanosaurs became the main group of large herbivorous tetrapods that inhabited the terrestrial ecosystems of the southern land masses (Bonaparte 1996, Leanza et al. 2004, Salgado and Coria 2005). Highly derived titanosaurs, the

Proceedings of the Third Gondwanan Dinosaur Symposium E-mail: pablogallina@gmail.com saltasaurines, were particularly uniform in their small size and morphology (J.E. Powell, unpublished data, Powell 2003), whereas earlier titanosaurids from Turonian-Campanian display a high diversity both in size and morphological characteristics (González-Riga 2003, Apesteguía 2004, Calvo and González-Riga 2003, Calvo et al. 2007). From Santonian-Campanian rocks of the Bajo de la Carpa Formation in Río Negro Province, Argentina, a partially articulated titanosaur, Bonitasaura salgadoi (Apesteguía 2004), has been recovered during successive field seasons since 2003 (Fig. 1).

This new sauropod brought to light new ideas about oral food processing in titanosaurs due to the probable presence of a sharp and straight mandibular crest posterior to the tooth row (Apesteguía 2004). Likewise, morphological novelties are present in the postcrania of Bonitasaura, which will be described here. 


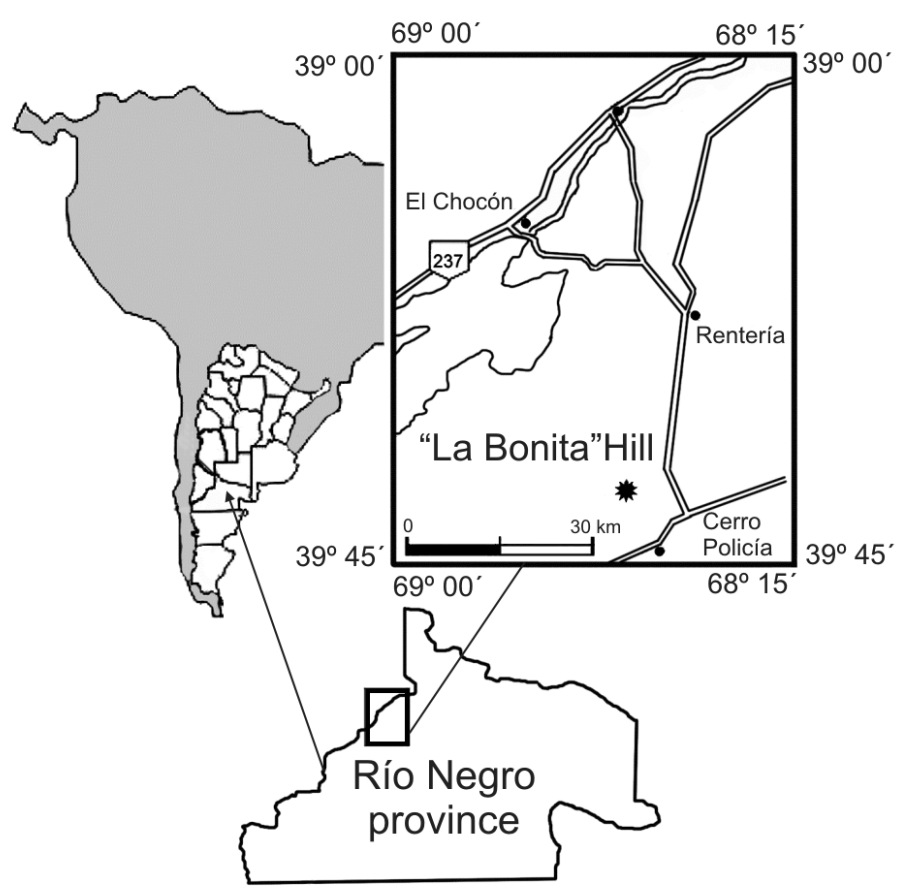

Fig. 1 - Map of "La Bonita” site, Río Negro province, Argentina, where Bonitasaura salgadoi was collected.

Sauropod axial anatomy is important in understanding morphological features and phylogenetic analyses (Bonaparte 1999, Wilson 1999). The spatial arrangement of zygapophyses and rib articulations, as well as their complex laminar development, help to distinguish the relative positions of isolated vertebral elements.

The vertebral remains of Bonitasaura include disarticulated vertebrae, but anterior, mid and posterior elements of cervical, dorsal and caudal series are present. This situation allows the analysis of other characteristics observed along the vertebral series.

Although a complete description of the axial skeleton of Bonitasaura is beyond the scope of this paper, several characteristics related to it are analyzed and discussed. These include the neurocentral closure pattern with its peculiar sequence, as well as several modifications in the neural spine and in the vertebral laminar arrangement.

\section{INSTITUTIONAL ABBREVIATIONS}

IANIGLA-Pv - Instituto Argentino de Nivología, Glaciología y Ciencias Ambientales, Mendoza, Argentina. MCF-PVPH - Museo Carmen Funes, Neuquén, Argentina.
MCT - Museu de Ciências da Terra, Rio de Janeiro, Brasil.

MPCA - Museo Provincial Carlos Ameghino, Río Negro, Argentina.

MPM - Museo Padre Molina, Santa Cruz, Argentina.

MUCPv-CePaLB - Museo de la Universidad Nacional del Comahue, Neuquén, Argentina.

\section{ANATOMICAL ABBREVIATIONS}

lsprl, lateral spinoprezygapophyseal lamina; msprl, medial spinoprezygapophyseal lamina; podl, postzygodiapophyseal lamina; spdl, spinodiapophyseal lamina; sprl, spinoprezygapophyseal lamina; spol, spinopostzygapophyseal lamina; tpol, intrapostzygapophyseal lamina; v.tpol, vertical intrapostzygapophyseal lamina.

\section{METHODS}

As mentioned above, vertebral elements of Bonitasaura (MPCA-460) were found disarticulated. However, the sequence of the dorsal series can be accurately determined. The assumed positions of the posterior cervical and the first three dorsal vertebrae (C13-D1-D2-D3) are indicated by the position of the parapophyses and the perfect articulation between these four elements, as well as by comparison with the corresponding segment 
in the vertebral series of Trigonosaurus pricei (Campos et al. 2005). Dorsal vertebrae 6? and 10? are positioned by comparison with Trigonosaurus (MCT 1488-R) and their dimensions and proportions, including neural arch height and position of the parapophyses.

The traditional "Romerian" anatomical nomenclature (Wilson 2006) is followed instead of that proposed by Weishampel et al. (1990) and Harris (2004).

\section{RESULTS}

In this section, three topics of the axial anatomy of Bonitasaura were analyzed: neurocentral closure; shape and orientation of the neural spine; and vertebral lamina homology and development.

Cervical and dorsal regions show some unfused neural arches, as well as some completely fused to their centra. On the other hand, in the caudal region, all neural arches and centra are fused. However, isolated transverse processes have been recovered, showing that the fusion of costal elements to vertebrae occurs after neurocentral closure (Gallina and Otero 2009). The different levels of fusion can be discriminated in order to recognize a precise temporal sequence. Unfused centra and neural arches with rugose contact surfaces (stage A, Fig. 2A, B), partially fused elements with neural arches resting on a position over the centra but with well visible sutures (stage B, Fig. 2C), and completely fused pieces with almost no sutures (stage C, Fig. 2D, E). An intermediate stage between $\mathrm{B}-\mathrm{C}$ can be observed in some elements of Bonitasaura (Fig. 2F, G). In the cervical region, several stages are present: stage $C$ (axis), stage A (two anterior cervical neural arches) and stage B-C (last cervical vertebrae). In the dorsal region, stage $\mathrm{A}$ (neural arch of dorsal vertebra 1), B (dorsal vertebra 3 ), and B-C (dorsal vertebrae 6? and 10?) are recognized. Finally, caudal vertebrae show stage B-C in anterior vertebrae and stage $\mathrm{C}$ with light sutures or without them. This peculiar sequence is a novelty for dinosaurs and will be discussed later.

Along the vertebral series, noticeable variations in neural spine morphology are observed. These variations include a range in lateral expansion of the dorsal tip and a marked deviation in cranio-caudal spine angulation.

The posterior cervical neural spines show a keyhole-shape in anterior view, with a rhomboidal tip. This tip is also seen in dorsal vertebra 1 and is reduced. From the second dorsal vertebra to posterior ones, the neural spine shape becomes laterally reduced (Fig. 3). This geometrical structure is composed of four main elements which reinforce the structure of the spine from its base by both spinoprezygapophyseal (sprl) and spinopostzigapophyseal laminae (spol). However, the contribution of both paired laminae to the lateral expansions cannot be discerned, and a simple union and thickening of the structure is, thus, assumed (Fig. 4 A, B). These lateral expansions are rather massive and rugose, suggesting a strong attachment site for epaxial musculature and cervical ligaments.

A marked variability of spinal orientation is evident in Bonitasaura when dorsal vertebrae are analyzed in lateral view, with the neural canal considered as an horizontal line. From the last cervical vertebra to the posterior dorsal vertebra, the spine is dorsoanteriorly oriented, then dorsoposteriorly, then vertical (Fig. 5A). This occurs gradually, but two recognizable landmarks (delimiting three vertebral regions) can be discriminated in order to standardize patterns of orientation in this portion of the column. The last cervical neural spine is dorsoanteriorly inclined 20 degrees from vertical, and, in the same way, the first dorsal neural spine inclines 15 degrees. The second dorsal neural spine is almost vertical. Between the second and the third dorsal vertebrae there is a conspicuous change in spinal orientation of around 25 degrees from vertical, turning the spine backwards. This is the first landmark and can be called D2-3 (= Dorsal vertebrae 2-3). The spinal inclination is dorsoposteriorly maintained in dorsal vertebra 6 , inclining 45 degrees to become vertical in dorsal vertebra 10?. Here is the second landmark, D9-10, but as D9 is absent in Bonitasaura, the point is more difficult to determinate here. In summary, posterior cervical and dorsal vertebrae of Bonitasaura show clear differences in spinal inclination which allow the division into three recognizable vertebral regions separated by two landmarks (see Discussion).

Finally, two additional observations can be made on the laminae of Bonitasaura. The first concerns the postzygodiapophyseal laminae (podl), and the second the intraposztygapophiseal laminae (tpol) (Fig. 6 A, B). By definition, the podl connect postzygapophyses with 


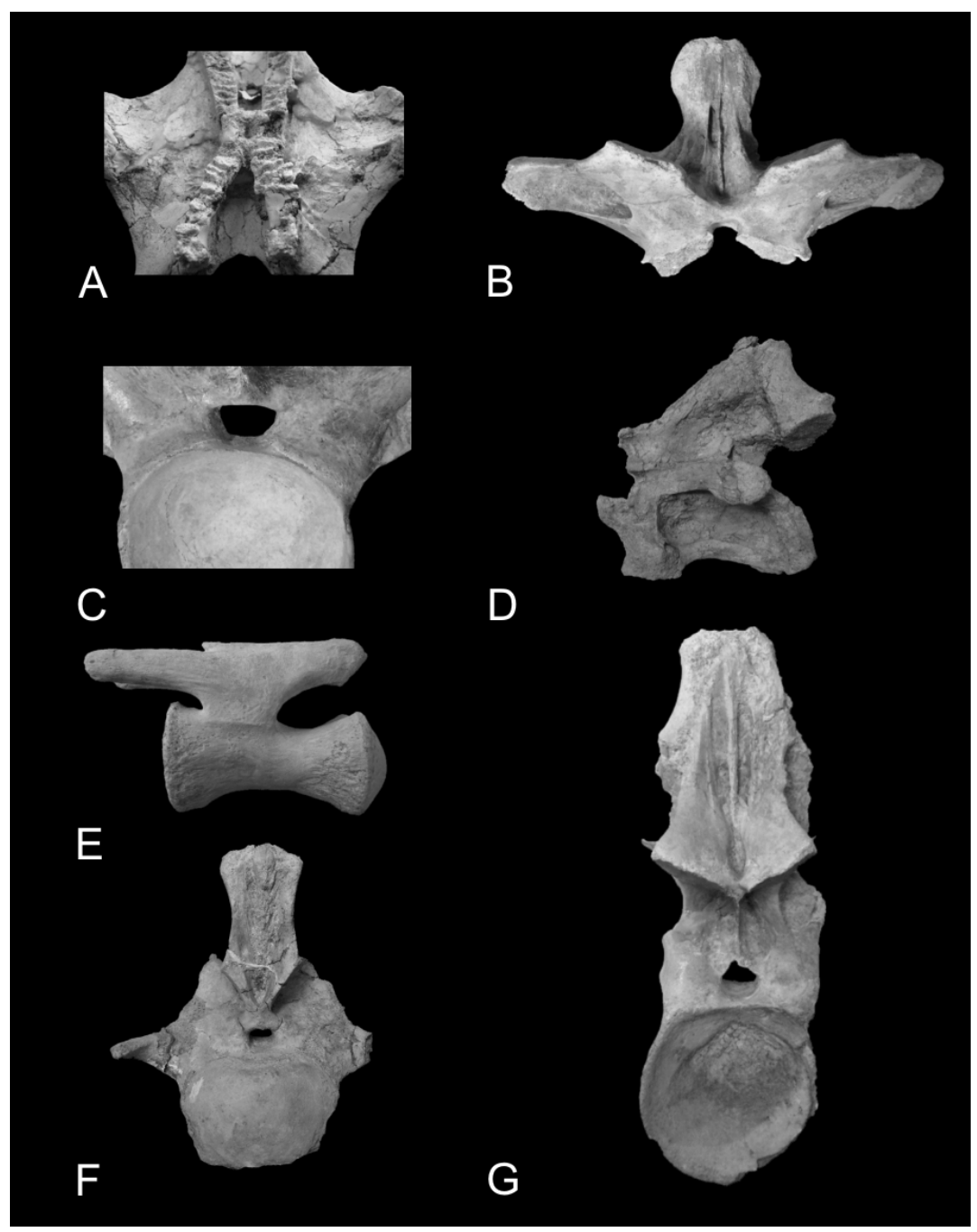

Fig. 2 - Axial skeleton elements of Bonitasaura salgadoi (MPCA-460) showing different degrees of neurocentral fusion. A - Unfused cervical neural arch with rugose contact surfaces in ventral view. B - Unfused dorsal neural arch with rugose contact surfaces in anterior view. C - Partially fused elements where the neural arch rests on dorsal centra with subtle sutures in posterior view. D - Completely fused axis with almost no suture in lateral view. E - Completely fused caudal vertebra with slight suture in lateral view. F - Intermediate state b-c in anterior caudal vertebra in posterior view. $\mathrm{G}$ - Intermediate state b-c in posterior dorsal vertebra in posterior view. Not to scale.

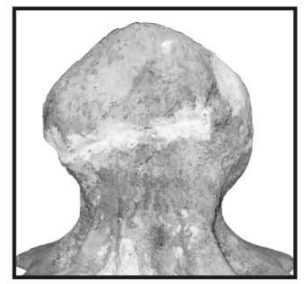

C13?

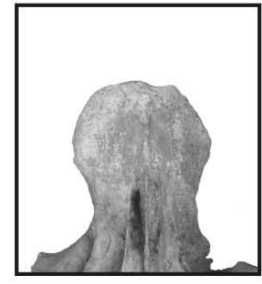

D1

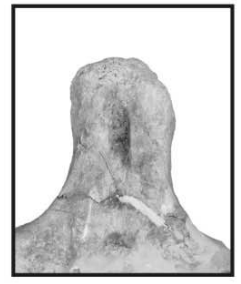

D2

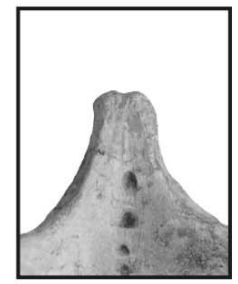

D3

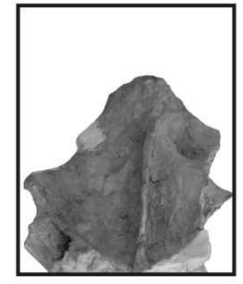

D6?

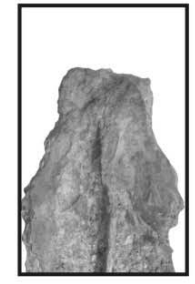

D10?

Fig. 3 - Neural spine morphology along the vertebral series of Bonitasaura salgadoi (MPCA-460) in anterior view. Abbreviations: C, cervical vertebra; D, dorsal vertebra. Not to scale. 


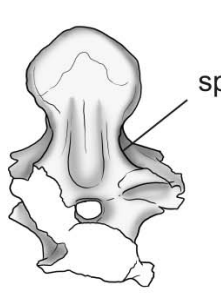

A

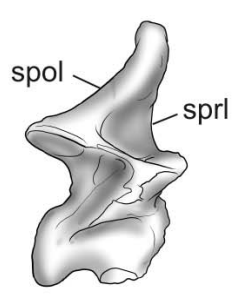

B

D

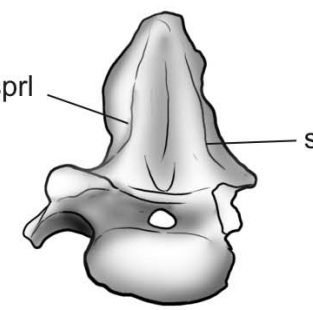

C

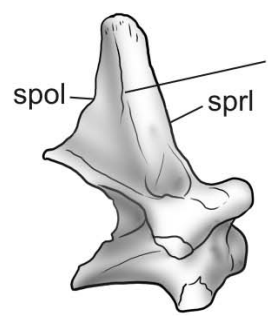

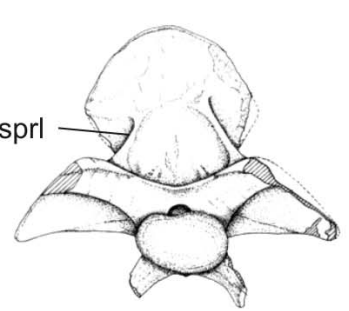

E

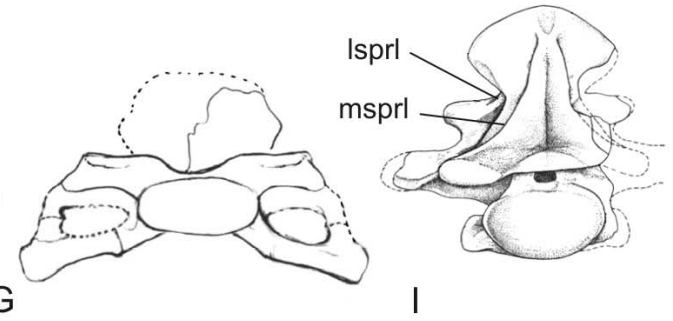

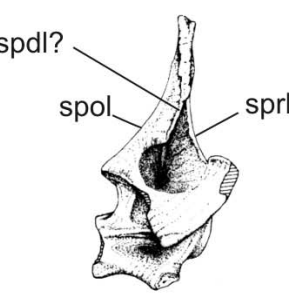

F

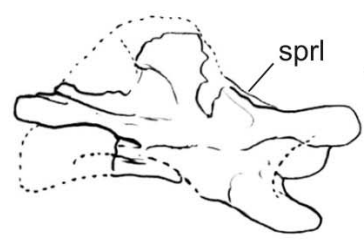

H

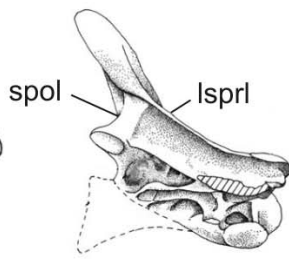

J

Fig. 4 - Posterior cervical vertebrae of several titanosaurs. Bonitasaura salgadoi (MPCA-460) in anterior (A) and right lateral (B) views. Futalognkosaurus dukei (MUCPv-323) in anterior (C) and right lateral (D) views (redraw from Calvo et al. 2007). Mendozasaurus neguyelap (IANIGLA-Pv-076) in anterior (E) and right lateral (F) views (from González-Riga 2005). Puertasaurus reuili (MPM-10002) in anterior (G) and right lateral $(\mathrm{H})$ views (from Novas et al. 2005). Ligabuesaurus leanzai (MCF-PVPH-233) in anterior (I) and right lateral (J) views (from Bonaparte et al. 2006). Abbreviations: 1sprl, lateral spinoprezygapophyseal lamina; msprl, medial spinoprezygapophyseal lamina; sprl, spinoprezygapophyseal lamina; spol, spinopostzygapophyseal lamina; spdl, spinodiapophyseal lamina. Not to scale.

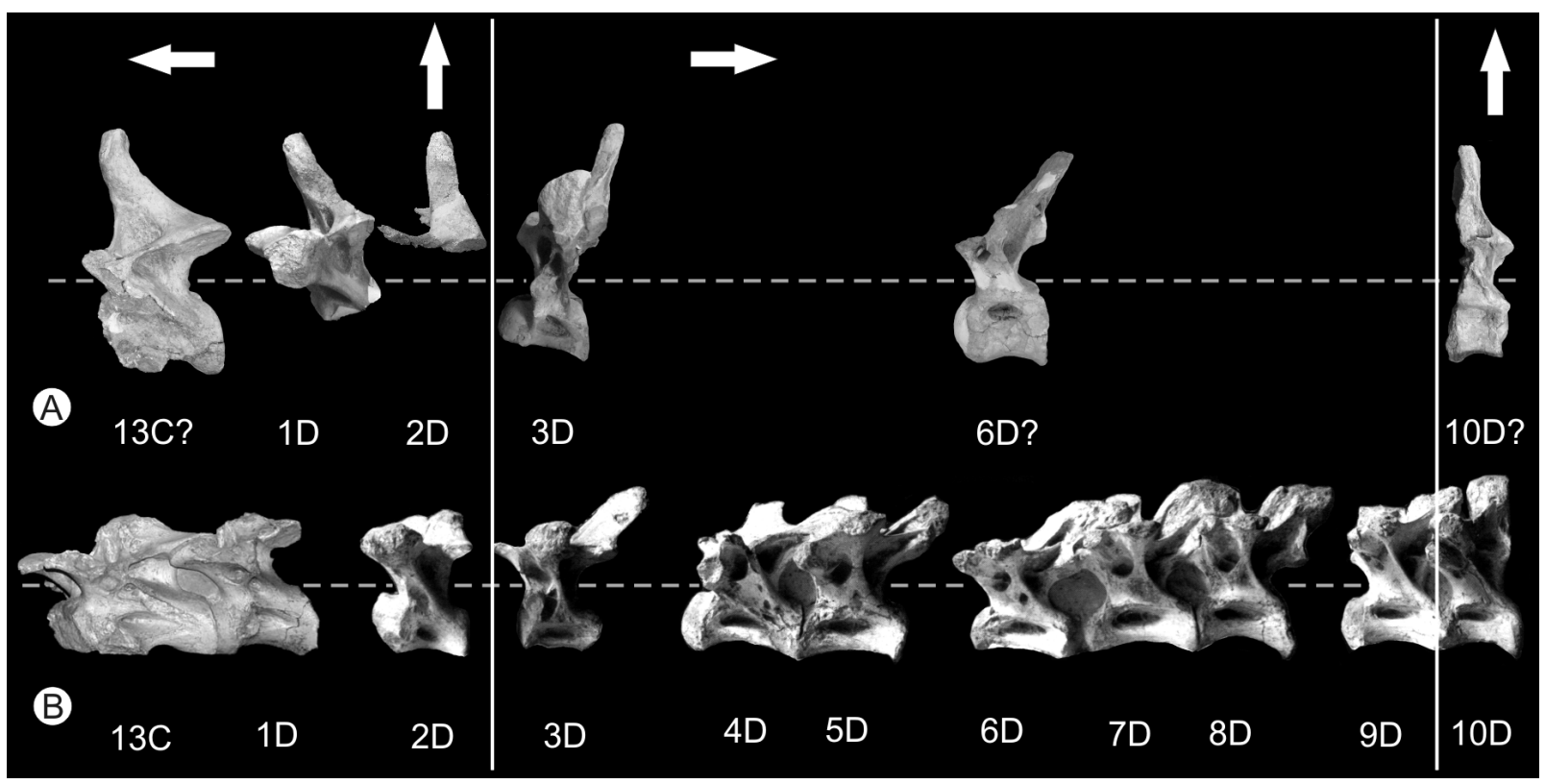

Fig. 5 - Orientation of neural spines along the vertebral series of two titanosaurs in lateral view. A - Posterior cervical and dorsal vertebrae of Bonitasaura salgadoi (MPCA-460) showing variation in spinal orientation. Dorsal vertebrae D1, D3 and D10 are inverted. The second dorsal vertebra is orientated after its articulation with the third dorsal vertebra. B - Posterior cervical and dorsal vertebrae of Trigonosaurus pricei (MCT 1488-R) showing variation in spinal orientation. Dotted lines are passing through the neural canal in horizontal position. Vertical lines show landmarks D2-D3 and D9-D10. Not to scale. 
diapophyses on the lateral surface. In the last cervical, the podl extends at an oblique angle from the postzygapophyses to the diapophyses. In dorsal vertebrae 1 and 2, this lamina is found in the same location, but in addition to connecting to the postzygapophysis, it rises dorsally to it. In dorsal 3 an interesting change is noticeable, the podl connection to the postzygapophyses is clearly disconnected and migrates dorsally, reaching the neural spine on its right lateral surface by mid-height. On dorsal vertebra 6?, the posterior part of the podl forms the main lateral aspect of the neural spine and a new incipient horizontal lamina arises from the postzygapophysis pointing towards the diapophysis. In dorsal 10 ?, this new lamina occupies the original location of the anterior dorsal podl, from postzygapophyses to diapophyses.

The intrapostzygapophyseal laminae also illustrate an interesting transition along the vertebral series. Both tpol converge at the midline over the neural canal, slightly pointing downwards in the last cervical vertebra. From the first dorsal vertebra and backwards along the series, a new vertical laminar component arises (here called v.tpol) and adds to the previously mentioned tpol. This lamina runs along the midline to reach the dorsal edge of the neural canal. In dorsal vertebra 1, v.tpol is nearly oblique, merging from the left postzygapophysis and delimiting two triangular fossae on each side. The tpol maintain their morphology, but showing a more marked V-shape. In dorsal vertebra 2, the region is damaged. In dorsal vertebra 3, a v-shaped tpol connects both postzygapophyses, whereas a vertical, thin, $4 \mathrm{~cm}$ long v.tpol can be recognized. In dorsal vertebra 6?, a short and nearly horizontal tpol is evident, although a v.tpol is not preserved. A smooth line in its location is present, so, the absence of v.tpol can be explained by preservational loss. Lastly, on dorsal vertebra 10?, the tpol is extremely reduced and only a very thin ( $2 \mathrm{~mm}$ in width) and $8 \mathrm{~cm}$ long v.tpol arises from the dorsal edge on the neural canal to reach the level of the postzygapophyses.

\section{DISCUSSION}

\section{NEUROCENTRAL CLOSURE}

The degree of fusion in vertebral elements has been used as a relative parameter of maturity (Brochu 1996), how- ever, the neurocentral closure (fusion of neural arch on vertebral body) is an area where the information is not obvious and needs to be tested with the addition of ontogenetic data (see Irmis 2007).

In extant archosaurs, two different patterns of neurocentral closure have been documented. In several genera of crocodilians, a posterior-anterior pattern of closure was recognized by Brochu (1996). In contrast, the pattern observed in aves appears to be in the opposite direction: anterior-posterior (Starck 1993, 1998). In extinct archosaurs, the condition is variable and different pathways are present (Irmis 2007). In ornithischian dinosaurs the pattern is anterior-posterior, at least in basal neoceratopsians (Chinnery and Weishampel 1998). In non-avian theropods the pattern is variable, with a posterior-anterior sequence seen in Dilophosaurus and Allosaurus, and others with different models or unknown (Irmis 2007). Within Sauropodomorpha, a generalized posterior-anterior pattern is present in basal forms as Thecodontosaurus and Unaysaurus, and also in basal Sauropoda as Antetonitrus and Isanosaurus (Irmis 2007). In Neosauropoda, a posterior-anterior pattern is present in Haplocanthosaurus and Apatosaurus (Irmis 2007). In Camarasaurus, the observed pattern does not follow an ordered sequence, but the closure begins with the posterior and middle caudals, anterior caudals, cervical vertebrae in anterior-posterior direction and finally dorsal vertebrae (Ikejiri 2003, Ikejiri et al. 2005).

Despite only one specimen being found, the sequence of closure in Bonitasaura can be analyzed based on different levels of fusion present in each region of the vertebral column at a single ontogenetic moment. This sequence can be explained by two different patterns when considering closure timing as a constant or as a variable rate between vertebrae.

In the first hypothesis (constant timing), the neurocentral fusion at the axis and caudal vertebrae are first in posterior-anterior direction; later, the simultaneous fusion of dorsal and cervical vertebrae in posterior-anterior direction takes place. The axis closure occurs very early in ontogeny for most reptiles (Romer 1956). However, in crocodilians, this fusion is one of the last to occur (C.A. Brochu, unpublished data). From the three stages of neurocentral fusion described before in Bonitasaura, 

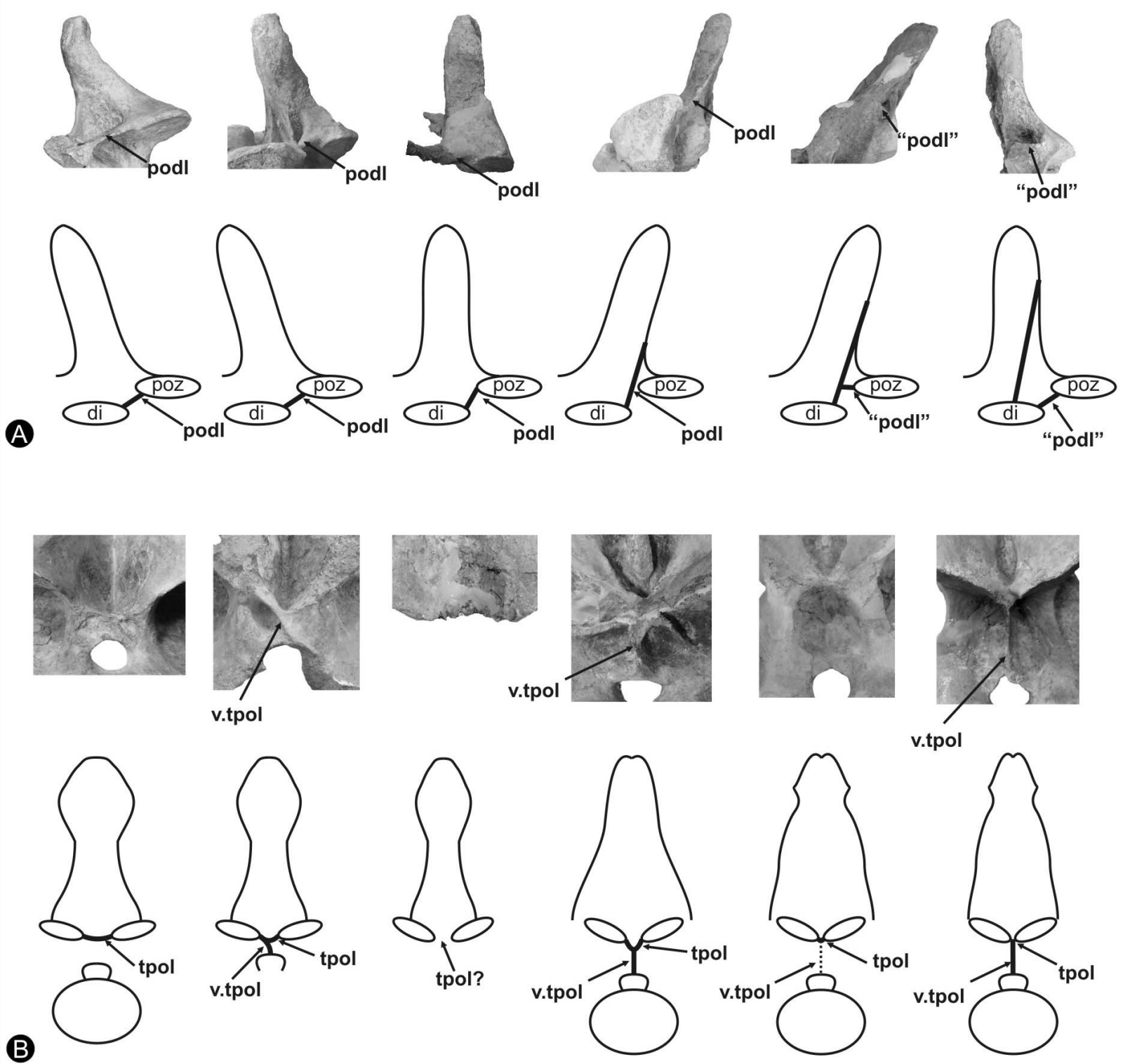

v.tpol

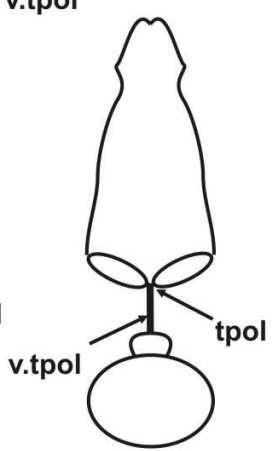

Fig. 6-Photographs and interpretative scheme showing the laminar arrangement in the vertebral series of Bonitasaura salgadoi. A-Development and position of postzygodiapophyseal lamina (podl) along the vertebral series. Note that posterior dorsal vertebrae have "podl” (not homologue to cervical podl). B - Development and position of intrapostzygapophyseal lamina (tpol) and new vertical intrapostzygapophyseal lamina (v. tpol) along the vertebral series. Not to scale.

the axis is in stage $\mathrm{C}$ of fusion, suggesting that its closure occurred early in ontogeny. Posterior caudal vertebrae also show a stage $\mathrm{C}$ of fusion. Later, two additional origin points for closure run from posterior to anterior in both dorsal and cervical regions, as inferred by the presence of fused elements posteriorly and unfused anteriorly.
Under the second hypothesis (variable timing), different results and conclusions are a priori very difficult to prove in fossils. This situation involves a simultaneous start point of closure from the posterior to the anterior of each region, with a marked reduction of velocity for dorsal and cervical regions. 
The sequence seen in Bonitasaura is novel and sheds light on how ossification patterns work along the vertebral column of a titanosaur.

\section{Neural Spine Shape, Conformation AND ORIENTATION}

Unusual cervico-dorsal neural spines with a rhomboid shape, laterally expanded, have been described in several titanosaurs, and some authors considered this particular morphology diagnostic both in basal and derived forms (i.e. Ligabuezaurus leanzai Bonaparte et al. 2006 and Mendozasaurus neguyelap González-Riga 2003). Calvo et al. (2007) recognized this spinal morphology in $F u$ talognkosaurus dukei Calvo et al. 2007 and suggested a similar character as a synapomorphy of a clade named Lognkosauria ("presence of a laterally expanded posterior cervical neural spines, wider than the centra"). The presence of a rhomboid-shaped neural spine, laterally expanded in the last cervical of Bonitasaura, as well as the presence of this morphology in other titanosaurs, suggest that this feature is widespread in Titanosauria.

Lateral expansions are the main characteristics for these rhomboid-shaped neural spines in the posterior cervical region, but differences arise in the laminar structures that result in this configuration (Fig. 4). In Bonitasaura and Puertasaurus reuili Novas et al. 2005 (MPM-10002), the lateral expansions are simple thickenings and expansions of the distal spine, without a clear contribution of anterior or posterior laminae (sprl and spol). Conversely, in Ligabuesaurus (MCF-PVPH-233), the lateral expansion involves lateral spinoprezigapophyseal laminae (1sprl, Bonaparte et al. 2006). In Mendozasaurus (IANIGLA-Pv-076) and Futalognkosaurus (MUCPv-323), a vertical lateral lamina is related with this structure. Although differences are observed in the osseous constituent elements of the generalized rhomboidal neural spine, a single morphogenetic event could be the responsible, showing the soft tissues' dominance on bone formation (Witmer 1997).

Despite the lack of complete titanosaur vertebral columns, the variable orientation of neural spines along the vertebral series is an interesting result. The observations made in Bonitasaura, as well as the recognition and comparison of a similar pattern in the well-known complete vertebral series from Trigonosaurus pricei
Campos et al. 2005, permit the identification of three angular sets and two orientation change landmarks from the last cervical to the posterior dorsal vertebrae (Fig. 5).

Powell (1987) recognized important changes in spinal orientation between dorsals 2 and 3 , and between dorsals 9 and 10 in the so called Brazilian "B series" (= Trigonosaurus pricei Campos et al. 2005). The former involves an orientation change from forwards to backwards, and the latter, also recognized by Campos et al. (2005), from backwards to vertical. This pattern is comparable with Bonitasaura when orienting the neural canal in a horizontal position. Thus, the recognition of these three angular sets and the two landmarks add supplementary information (to other vertebral characteristics such as spatial arrangement of zygapophyses, rib articulations and vertebral laminae) for the recognition of an accurate position for isolated axial elements along a vertebral series.

\section{Vertebral Laminae Homology and DeVelopment}

Early laminar classifications highlighted orientation rather than element connections (see Wilson 1999). Wilson (1999) proposed a very useful laminar nomenclature for sauropod dinosaurs based on morphological landmarks; the name of each lamina, thus, reflects the connection points on the vertebrae. However, in analyzing almost complete titanosaur vertebral series, several laminae disconnections occur from their original anatomical points to take new positions, with significant consequences on their homology and, therefore, nomenclature. One example of this change can be observed in the postzygodiapophyseal lamina (podl) (Salgado et al. 2006, Salgado and Carvalho 2008). In several titanosaurs, such as Alamosaurus, Trigonosaurus, Uberabatitan and Bonitasaura, this lamina disconnects from postzygapophysis and migrates up on the lateral aspect of the neural spine through the dorsal series (the migration sequence is observable in Trigonosaurus and Bonitasaura). The final result is a new position for the original podl in posterior dorsals occupying the place expected for the spdl. This situation occurs in parallel to a marked reduction of the spdl, which tends to disappear (Salgado et al. 2006). As a consequence, the lamina between diapophyses and postzygapophyses observed in the dorsal vertebra 10 both in Trigonosaurus 
and Bonitasaura is not homologous to podl (contra Campos et al. 2005) (Fig. 6A). Recently, Salgado and Coria (2009) and Salgado and Powell (2010) proposed other scenarios concerning the lateral laminae of dorsal vertebrae. In their proposal, a bifurcation of spinodiapophyseal laminae in anterior spdl and posterior spdl, and the maintenance of podl for the lamina uniting postzygapophyses and diapophyses, occur in posterior dorsal vertebrae. However, as explained above, this is not the case observed in Bonitasaura.

Another situation is present in intrapostzygapophyseal laminae along titanosaur vertebral series. Intrapostzypgapophyseal laminae are defined by Wilson (1999:647) as "the paired laminae originated on medial aspect of the postzygapophyses and project medially to meet on the midline above the posterior opening of neural canal". He also remarked "the tpol's may connect to the neural canal via a vertical strut", considering this vertical structure as the result of joint of the paired laminae. Apesteguía (2005) also recognizes a paired laminar origin for tpol and a later fusion in a single vertical structure. However, as it is observed in Bonitasaura, Rapetosaurus (Curry Rogers 2009) and Mendozasaurus (pers. obs.), both structures are different in origin and, hence, should receive a different name. The key point for its recognition is in dorsal 1 or 2 . In both Bonitasaura and Mendozasaurus, a well developed oblique lamina runs from the medial side of left postzygapophyses to the neural canal dorsal border. The first segment (proximally to postzygapophyses) is fused with the left part of the intrapostzygapophyseal laminae (Fig. 6B), but an independent origin is recognizable and, hence, v.tpol is proposed for this single lamina. Whereas this vertical lamina persists until the posterior dorsal vertebrae in Bonitasaura, in Rapetosaurus it persists through the middle of the dorsal series. As proposed by Apesteguía (2005), hyposphenes are the result of the hypertrophy of a multilaminar system including intrapostzygapophyseal and centropostzygapophyseal laminae. In this sense, v.tpol seems to be the main component in sauropods with such accessory articulation elements.

Finding isolated or disarticulated vertebral elements in titanosaurs is common and, thus, laminar study is often made using single comparisons devoid of serial correlation. This results in erroneous assumptions in laminar recognition. The analysis portrayed here demonstrates the importance of examining a complete vertebral series in order to recognize laminar homologies.

\section{CONCLUSIONS}

Several areas of the vertebral anatomy of Bonitasaura salgadoi were described and discussed.

The neurocentral closure was analyzed providing a particular temporal sequence for the first time in a titanosaur. The sequence of closure is different under two hypotheses if considering closure timing as constant or variable, but an unordered sequence, which includes independent posterior-anterior fusion of caudal, dorsal and cervical regions, is documented.

The analysis of the shape, constituents and orientation of the neural spine along the vertebral series in Bonitasaura shows unusual characteristics for titanosaurs. The presence of a rhomboidal neural spine, laterally expanded, is recognized in basal and derived forms of titanosaurs, suggesting that this feature is widespread within Titanosauria. The variable spinal orientation found in Bonitasaura permitted the recognition of three angular sets and two landmarks, improving the identification of an accurate position along the vertebral series for isolated axial elements.

Finally, the study of several vertebral laminae reveals the importance of examining the vertebral series in order to recognize laminar homologies and development series. In this way, two laminae were reevaluated: podl connecting postzygapophyses with diapophyses in posterior dorsal vertebrae, and v.tpol connecting the dorsal edge of neural canal with the intrapostzygapophyseal lamina.

\section{ACKNOWLEDGMENTS}

I deeply thank Sebastián Apesteguía, Leonardo Salgado, Mike D'Emic and Takehito Ikejiri for discussion and useful comments in early stages of the manuscript. I also thank Dr. Alexander Kellner and Dr. Yukimitsu Tomida, editors of the Gondwanan dinosaurs and associated fauna volume, for the opportunity to participate in this contribution. Rosie Barnes has improved the English style of the manuscript, and D. Riff the Portuguese translation of the abstract. I appreciated the 
critical comments and suggestions made by the anonymous reviewers. Funds were provided by Jurassic Foundation and Fundación de Historia Natural Félix de Azara-Universidad Maimónides.

\section{RESUMO}

A anatomia axial dos saurópodes compõe um conjunto de dados fundamentais para a caracterização morfológica dos táxons, bem como para a determinação de suas relações filogenéticas. A disposição espacial das zigapófises e articulações das costelas, assim como de seu complexo de lâminas acessórias, auxiliam no reconhecimento da posição relativa de elementos vertebrais isolados. A preservação de vértebras anteriores, médias e posteriores nas séries cervical, dorsal e caudal de Bonitasaura salgadoi permite a análise de características adicionais diagnósticas observadas ao longo das séries vertebrais. Estas incluem o grau de fusão da sutura neurocentral, havendo elementos livres, parcialmente fundidos a completamente fundidos em uma sequência temporal peculiar, assim como a presença de diversas modificações do espinho neural e a disposição laminar. As variações na morfologia do espinho neural incluem uma expansão lateral em seu ápice distal na região cervico-dorsal, outros componentes laterais distintos destas expansões, e um desvio crânio-caudal marcado pela angulação do espinho neural. A inclinação espinal permite a divisão em três segmentos vertebrais reconhecíveis separados por duas linhas de transição. Finalmente, a análise das lâminas vertebrais revela a importância de examinar a série vertebral a fim de reconhecer homologias nas lâminas e nas séries de desenvolvimento. Neste trabalho são analisadas duas lâminas vertebrais.

Palavras-chave: Dinosauria, esqueleto axial, sutura neurocentral, Sauropoda, Titanosauria, lâminas vertebrais.

\section{REFERENCES}

Apesteguía S. 2004. Bonitasaura salgadoi gen. et sp. nov.: a beaked sauropod from the Late Cretaceous of Patagonia. Naturwissenschaften 91: 493-497.

APESTEGUíA S. 2005. Evolution of the hyposphene-hypantrum complex within Sauropoda. In: TIDWELL V AND CARPENTER K (Eds), Thunder-lizards: the Sauropodomorph dinosaurs. Indiana University Press, Bloomington, p. $248-267$.

Bonaparte JF. 1996. Cretaceous Tetrapods of Argentina. In: Pfeil F AND Arratia G (Eds), Contributions of southern South America to Vertebrate Paleontology. Münchner Geowissenschaftliche Abhandlungen. Reihe A Geologie und Paläontologie 30: 73-130.

BONAPARTE JF. 1999. Evolución de las vértebras presacras en Sauropodomorpha. Ameghiniana 36: 115-187.

Bonaparte JF, GonzÁlez-Riga BJ And Apesteguía S. 2006. Ligabuesaurus leanzai gen. et sp nov. (Dinosauria, Sauropoda), a new titanosaur from the Lohan Cura Formation (Aptian, Lower Cretaceous) of Neuquén, Patagonia, Argentina. Cret Res 27: 364-376.

BROCHU CA. 1996. Closure of neurocentral sutures during crocodilian ontogeny: implications for maturity assessment in fossil archosaurs. J Vert Paleont 16: 49-62.

CAlvo JO And GonzÁlez-Riga BJ. 2003. Rinconsaurus caudamirus gen. et sp. nov., a new titanosaurid (Dinosauria, Sauropoda) from the Late Cretaceous of Patagonia, Argentina. Rev Geol Chi 30: 333-353.

Calvo JO, Porfiri JD, GonzÁlez-Riga BJ AND KellNER AWA. 2007. A new Cretaceous terrestrial ecosystem from Gondwana with the description of a new sauropod dinosaur. An Acad Bras Cienc 79: 529-541.

CAmpos DA, Kellner AWA, Bertini RJ And SANTuCCI RM. 2005. On a titanosaurid (Dinosauria, Sauropoda) vertebral column from the Bauru Group, Late Cretaceous of Brazil. Arq Mus Nac Rio de Janeiro 63: 565-593.

Chinnery BJ And Weishampel DB. 1998. Montanoceratops cerorhynchus (Dinosauria: Ceratopsia) and relationships among basal neoceratopsians. J Vert Paleont 18: 569-585.

CURry Rogers KA. 2009. The postcranial osteology of Rapetosaurus krausei (Sauropoda: Titanosauria) from the Late Cretaceous of Madagascar. J Vert Paleont 29: 10461086.

GALlina PA AND OTERo A. 2009. Anterior caudal transverse processes in sauropod dinosaurs: morphological, phylogenetic and functional aspects. Ameghiniana 46: 165-176.

GonZÁLEZ-Riga BJ. 2003. A new titanosaur (Dinosauria, Sauropoda) from the Upper Cretaceous of Mendoza, Argentina. Ameghiniana 40: 155-172.

GonZÁLEZ-RigA BJ. 2005. Nuevos restos fósiles de Mendozasaurus neguyelap (Sauropoda: Titanosauridae) del Cretácico Tardío de Mendoza, Argentina. Ameghiniana 42: 535-548.

HARRIS JD. 2004. Confusing dinosaurs with mammals: tetrapod phylogenetics and anatomical terminology in the world of homology. The Anatomical Record 281A: 1240-1246. 
IKEJIRI T. 2003. Sequence of closure of neurocentral sutures in Camarasaurus (Sauropoda) and implications for phylogeny in Reptilia. J Vert Paleont 23: 65A.

IkeJiri T, Tidwell V AND TReXler DL. 2005. New adult Specimens of Camarasaurus lentus Highlight Ontogenetic Variation within the Species. In: TIDWELL V AND CARPENTER K (Eds), Thunder-lizards: the Sauropodomorph dinosaurs. Indiana University Press, Bloomington, p. 154-179.

IRMIS RB. 2007. Axial skeleton ontogeny in the Parasuchia (Archosauria: Pseudosuchia) and its implications for ontogenetic determination in archosaurs. J Vert Paleont 27: 350-361.

Leanza HA, Apesteguía S, Novas FE and De La FUENTE MS. 2004. Cretaceous terrestrial beds from the Neuquén basin (Argentina) and their tetrapod assemblages. Cret Res 25: 1-96.

Novas FE, Salgado L, Calvo JO And Agnolin F. 2005. Giant titanosaur (Dinosauria, Sauropoda) from the Late Cretaceous of Patagonia. Rev Mus Arg Cs Nat 7: $37-41$.

Powell JE. 1987. Morfología del esqueleto axial de los titanosauridos (Saurischia-Sauropoda) del Estado de Minas Gerais, Brasil. Anais do X Congresso Brasileiro de Paleontología, p. 155-177.

Powell JE. 2003. Revision of South American Titanosaurid dinosaurs: palaeobiological, palaeobiogeographical and phylogenetic aspects. Records of the Queen Victoria Museum, n. 111, Launceston, 173 p.

ROMER AS. 1956. Osteology of reptiles, Chicago: The University of Chicago Press, $770 \mathrm{p}$.

SALGADO L AND CARVALHO IS. 2008. Uberabatitan ribeiroi, a new titanosaur from the Marília Formation (Bauru Group, Upper Cretaceous), Minas Gerais, Brazil. Palaeontology 51: 881-901.

SAlgado L AND Coria RA. 2005. Sauropods of Patagonia: Systematic update and notes on global sauropod evolution. In: Tidwell V AND CARPENTER K (Eds), Thunder-lizards: the Sauropodomorph dinosaurs. Indiana University Press, Bloomington, p. 430-453.
SAlGADO L AND CORIA RA. 2009. Barrosasaurus casamiquelai gen. et sp. nov., a new titanosaur (Dinosauria, Sauropoda) from the Anacleto Formation (Late Cretaceous: early Campanian) of Sierra Barrosa (Neuquén, Argentina). Zootaxa 2222: 1-16.

SAlgado L, GARCíA RA AND DAZA JD. 2006. Consideraciones sobre las laminas neurales de los dinosaurios saurópodos y su significado morfofuncional. Rev Mus Arg Cs Nat 8: 69-79.

Salgado L And Powell JE. 2010. Reassessment of the vertebral laminae in some South American titanosaurian sauropods. J Vert Paleont 30: 1760-1772.

StARCK JM. 1993. Evolution of avian ontogenies. Current Ornithology 10: 275-366.

STARCK JM. 1998. Structural variants and invariants in avian embryonic and postnatal development. In: STARCK JM AND RiCKLEFs RE (Eds), Avian Growth and Development: Evolution within the Altricial-Precocial Spectrum. Oxford University Press, New York, p. 59-88.

Weishampel DB, Dodson P AND OSMÓlsKa H. 1990. The Dinosauria, Berkeley: The University of California Press, $732 \mathrm{p}$.

WILSON JA. 1999. A nomenclature for vertebral laminae in sauropods and other saurischian dinosaurs. J Vert Paleont 19: 639-653.

WILSON JA. 2006. Anatomical nomenclature of fossil vertebrates: standardized terms or lingua franca? J Vert Paleont 26: 511-518.

WiTMER LM. 1997. The evolution of the antorbital cavity in archosaurs: a study in soft-tissue reconstruction in the fossil record with an analysis of the function of pneumaticity. Soc Vert Paleont, Mem 3: 1-73. 